UDC $14+37.01$

DOI: https://doi.org/10.30839/2072-7941.2018.149670

\title{
PHILOSOPHICAL EDUCATION IN THE CONTEXT OF THE IDEA SMART SOCIETY
}

\author{
(C) VISHNEVSKY, M. I. \\ Mogilev State A. Kuleshov University (Mogilev, The Republic Of Belarus) \\ E-mail: philos-mogilev-msu@mail.ru, ORCID 0000-0001-6603-0534
}

The article presents the conceptualization of philosophical education, in the context of which the evolution of the development of society from informational to smart society takes place. The purpose of the article is to reveal the conceptualization of philosophical education in the context of the idea of a smart society and to show that philosophical education does not stand still but develops along with the development of science and technology, which requires the development of a conceptual and categorical apparatus. Research objectives: to show the development of philosophical knowledge, in the context of which new innovative ideas are ripening; to reveal that the concept of a smart society is based on the expectation or belief in the ability of modern smart technologies to positively influence social processes and lead to a new qualitative state of all social life, which is called a smart society; to prove that much in solving all these problems depends on the state of education, including philosophical and ideological, not only developing our cognitive abilities, but also forming a responsible and demanding attitude to goal setting, the choice of basic life values. Analysis of recent research and publications, which presents a solution to this problem. We rely on the works of I.Ardashkin, V.Voronkova, M.Kastels, O.Kivlyuk, K.Korsak, A.Lazarevich, R.Oleksenko, O.Punchenko, which in one way or another reflected the problem of the formation of a smart society. The research methodology is the dialectical, historical, systemic, informational methods, which allowed to penetrate deeply into the evolution of philosophical knowledge that is not in mass, but develops with the development of science, technique and technology. The result of research - based smart society the development of information and computer technologies that lead to breakthrough technologies and innovative development It is noted that the proposed reorganization of the system of social-humanitarian education in the universities of the Republic of Belarus intended to raise to the level of philosophical training of domestic specialists.

Keywords: philosophy, socio-cultural situation, philosophical doctrine, the "spirit of freedom", the reorganization of the philosophical and educational knowledge, Belarus, smart society, smart technology

The statement of the problem in its most general form and its connection with the most important scientific and practical tasks.

In this article we will try to apply a philosophical approach to the activity of philosophical education, which does not require an exhaustive comprehensiveness of the empirical material, but concentrates on the most common connections and relations expressing the integrity and basic dynamics of the phenomenon under study, its particular place in the structure of social being. It should be borne in mind that even when conceived and built as a consistent conceptual and logical construction based on clearly defined principles, the philosophical concept has unprovable beginnings within its framework. Following these initial 
positions informs her in many ways a hypothetical, conjectural character. The stricter and more consistent the philosophical and ideological theory, the more restrictions it imposes on the coverage of specific details of cultural-historical and cognitive experience, disregarding or referring to its insignificant many of its moments. But the peak of the popularity of great philosophical systems has long passed; nowadays they do not inspire unconditional trust in the thinking public, although they retain their value as important illustrations in the academic presentation of philosophy.

The purpose of the article is to reveal the conceptualization of philosophical education in the context of the idea of a smart society and to show that philosophical education does not stand still but develops along with the development of science and technology, which requires the development of a conceptual and categorical apparatus.

\section{Objectives of the study:}

- to show the development of philosophical knowledge, in the context of which new innovative ideas are ripening;

- to reveal that the concept of smart society is based on the expectation or belief in the ability of modern smart technologies to positively influence social processes and lead to a new qualitative state of all social life, which is called smart society;

- to prove that much in solving all these problems depends on the state of education, including philosophical and ideological, not only developing our cognitive abilities, but also forming a responsible and demanding attitude to goal setting, the choice of basic life values.

Analysis of recent research and publications, which presents a solution to this problem. We rely on the works of I.Ardashkin, V.Voronkova, M.Kastels, O.Kivlyuk, K.Korsak, A.Lazarevich, R.Oleksenko, O.Punchenko, which in one way or another reflected the problem of the formation of a smart society.

\section{Discussion of the problem}

In-depth understanding of the current sociocultural situation requires taking into account all the diversity of philosophical doctrines and ideas, not only advanced relatively recently, but also constituting the basic historical and philosophical tradition and, at the same time, functioning in the culture of our days. The total array of these concepts is in a definite (far from straightforward and unambiguous) connection with the diversity of people's life positions and the ways they realize their life world. If the philosophical idea turned out to be consonant with the mindsets of many people, this means that the philosopher managed to express in a generalized and distinct conceptual form what already seems to be in the air, is present in attitudes, aspirations and assessments of his contemporaries. But in order for people to recognize themselves in this idea, it must be conveyed to them in an understandable and, at the same time, undistorted form. This can be achieved mainly through appropriate educational activities [2], the content and results of which have a chance to 
become influential cultural phenomena.

Philosophy, initially and in essence, has an educational orientation; it is, as it were, intended to be studied, pondered and incorporated into the worldview of the forming personality as a deeper, rather than ordinary, understanding of the surrounding reality and its place in it. Philosophical positions are mainly formulated as special, theoretically ordered and expressed in conceptual and logical form, world outlook knowledge, connecting and relating everyday and religious experience, the scientific interpretation of the world and political, economic and other specialized practices.

Different philosophical teachings give in many respects different "cuts" of being and consciousness of people, however, complementing each other to some desired and difficult to achieve integrity. An individual person, busy with his own affairs and not claiming to be a universal philosophical erudition, is hardly able to independently embrace and realize this integrity. A qualitative ideological education is meant to lead to the idea that reality is more complicated than any one-sided picture of it, and one should not absolutize any limited viewpoint on world existence, even if politics, ideology or advertising insist on such absolutization.

It should be noted here that the "spirit of the epoch" is capable of expressing not only philosophy as a special specialized activity of theoretical and ideological research, but also other forms of social consciousness. There is no need to discuss in detail the fact that in the past religion successfully coped with this function. Nowadays, in many regions of the world, a peculiar religion or, better to say, an ideology of success (primarily economic, but also political, etc.) continues to function as the basis of the worldview.

In consonance with the era, new scientific ideas are often found. Presumably, the very wide popularity of the mechanistic world outlook, which at one time turned out to be consonant with the views and aspirations of entrepreneurs who mastered machine technology and easily accepted the idea of the world as a complex machine created by God, is not accidental. Later, the idea of evolution, which extensively interpreted Darwin's teaching, came to the fore in European culture. At the beginning of the 20th century, the minds of educated people were captured by the idea of relativity, which, although born in one of the specialized branches of physics, was close to the mindsets of people who survived the cultural catastrophe of the First World War.

At about the same time, the ideas of complementarity and the uncertainty relation, borrowed from physics, became widely popular. In the second half of the 20th century, synergetic ideas (imbalance and instability, bifurcations, spontaneous emergence of order from chaos, etc.) acquired general cultural significance. Recently, in connection with the development of the Internet, the "network picture" of social reality has become widespread [5, p. 208 - 213].

In general, it can be stated that philosophical and ideological creativity has long ceased to be a 
matter of only a relatively narrow group of professional philosophers; It also actively includes some people in science and art, politics, ideology, and economics. "Philosophizing, - notes TV Kudryashova, - incomparably more than philosophers ... A philosopher is a unique phenomenon in culture, it is a single event for a generation, and not every generation" [4, p. 100].

In connection with the abundance of philosophizing subjects, there is the problem of wide dissemination in the culture of solid historical and philosophical knowledge, which gives world-view-active individuals the necessary information about how philosophical understanding of being was carried out in the past and what or other absolutization effects led to. When studying philosophy in higher education institutions, it would be wrong to confine ourselves to a cursory presentation of the "general philosophy", which is characterized by averaged and primarily applied orientation, without pretending to thoroughly cover the underlying ideas that make up the essence of philosophical concepts that are most significant in culture.

The planned reorganization of the system of social and humanitarian education in the universities of the Republic of Belarus is designed to raise to a proper level the philosophical and ideological training of domestic specialists. This reorganization can be correlated with the general movement leading to a certain new state of social life, which is not fully reflected in the already familiar notions of "information society" or "knowledge society". In a vast and ever-growing literature on these types of society, for some time there has been a shortage of fresh and constructive ideas.

Since the flow of publications on the social and spiritual realities of our days should not dry out, special attention is paid to the new sources that feed it. One of them is associated with the somewhat uncertain, but generally inspiring, concept of optimism with the concept of a smart society. An analytical article by I. B. Ardashkin on smart society [1] notes that this concept is based on the expectation or belief in the ability of modern smart technologies to positively influence social processes and lead to a new qualitative state of all social life, which is called smart society.

The concept of smart technology covers a very wide range of phenomena, ranging from being involved in the Internet with its diverse databases and right up to organizing effective interaction between people and technologies in order to increase safety and improve the quality of life [1]. However, the uncertainty of this concept affects the interpretation of all those phenomena of social life, the name of which receives the prefix "smart", designed to denote their transition to a new, higher quality.

Free operation with such concepts (smart education, smart goal-setting, smart environment, smart interaction, smart city, smart society and even smart life) can give the impression of a meaningful movement of thought, but its results are sometimes frankly disappointing. It turns out, in particular, that innovations based on 
information-computer technologies, solving some problems (economic, technical and technological, sociocultural or other kind), create others, and their interweaving and complication deprives us of hope for rapid and guaranteed progress.

Much in solving all these problems depends on the state of education, including philosophical and ideological, not only developing our cognitive abilities, but also forming a responsible and demanding attitude to goal-setting, the choice of basic life values. Despite the fact that philosophical ideological knowledge is predominantly theoretical, familiarizing with them has a deep life-practical meaning. Unlike the concrete sciences, philosophy as a whole claims to build an integral picture of the world of human existence.

The problem of our being diverse and multi-level; Awareness of its true scale and characteristics is achieved very difficult. When dealing with the chaotic, at first glance, interweaving and interaction of various phenomena and processes affecting our life, people, based on the education they have received, usually seek to systematize them, spreading them out according to specific headings related to this or that science. . It is assumed that every science is able to find a constructive solution to its class of problems, and as a result of such partial and multidirectional efforts, it will be possible to move towards a more prosperous and rational, or "smart," state of life in general. The existing educational organization in many respects contributes to consolidating this illusion, because it focuses on the training of professionals who are competent in certain narrow areas of activity [3, p. 59 - 66].

\section{Findings}

At the same time, experts in the field of management have long ago shown that the behavior of a complexly organized system depends more on the general state of relations between its elements and levels than on solving, even if successful, individual problems. Effective management is the management of interactions, rather than individual actions. Such management requires not so much analytical thinking, as thinking synthetic, based on a basic understanding of the situation as a whole. But this is precisely the basic orientation of philosophical and ideological education, aimed not at mastering a particular doctrine, but at understanding specific specificity and corresponding productivity, but also the limitations of various philosophical concepts that complement each other to some desired, clearly not articulated and, however, the only effective integrity.

An integral and non-dogmatic understanding of the world of our being is, it seems, a necessary condition for successful advancement to a truly rational state of social life. As applied to the organization of philosophical and ideological education, this means the unproductiveness of the installation of a fragmentary presentation of certain provisions expressed by various thinkers on a particular issue, without taking into account the integrity of their position, originality of arguments the socio-cultural context of the 
teachings developed by them, and the cultural and educational philosophical urgent need to implement a broad synthesis.

\section{References}

1. Ardashkin, I. B. (2017). Smart-society as a stage of development of new technologies for society or as a new of social development (progress): to the problem of the problem. Vestnik Tomskogo Gosudarstvennogo Universiteta. Filosofiya. Sotsiologiya. Politologiya, 38, 32-45. doi: https://doi.org/10.17223/1998863x/38/4

2. Vishnevskiy, M. I. (2015). Ob izuchenii filosofii. Optimizaciya social'nogumanitarnogo obrazovaniya v vuze. Mogilev: MGU im. A. A. Kuleshova, 7-31.

3. Vishnevskiy, M. I. (2018). Kul'turno-obrazovatel'niy sintez: ponyatie i problemy. Filosofiya i/ili novoe integrativnoe znanie. Yaroslavl': RIO YAGPU.

4. Kudryashova, T. V. (2018). Mul'tiagentnaya paradigma kak variant mezhdisciplinarnosti. Filosofiya i/ili novoe integrativnoe znanie. Yaroslavl': RIO YAGPU.

5. Nacional'naya filosofiya $\mathrm{v}$ global'nom mire: tezisy Pervogo belorusskogo filosofskogo kongressa (2017). Minsk: Belarus. navuka, 765.

ВИШНЕВСЬКИЙ, М. І. - доктор філософських наук, професор, Заслужений працівник освіти Республіки Білорусь, завідуючий кафедрою філософії Могилевського державного університету імені А. Кулешова (Могилев, Республіка Білорусь)

E-mail: philos-mogilev-msu@mail.ru, ORCID 0000-0001-6603-0534

\section{ФІЛОСОФСЬКА ОСВІТА У КОНТЕКСТІ ІДЕЇ СМАРТ-СУСПІЛЬСТВА}

У статті представлена концептуалізація філософської освіти, у контексті якої відбувається еволюція розвитку суспільства від інформаційного до смарт-суспільства. Мета статті - розкрити концептуалізацію філософської освіти у контексті ідеї смартсуспільства і показати, що філософська освіта не стоїть на місці, а розвивається разом 3 розвитком науки і техніки, що вимагає і розвитку поняттєво-категоріального апарату. Задачі дослідження: показати розвиток філософського знання, в контексті якого визрівають нові інноваційні ідеї; виявити, що концепція смарт-суспільства базується на очікуванні і переконанні у здатності сучасних смарт-технологій ефективно вплинути на соціальні процеси і привести до нового якісного стану всього суспільного життя, яке і називають смарт-суспільством; довести, що багато у вирішенні всіх цих проблем залежить від стану освіти, у тому числі і філософсько-світоглядяної, не тільки як такої, що розвиває наші пізнавальні здібності, але й формує відповідальне і сумлінне відношення до цілепокладання, вибору базових життєвих цінностей. Ми спираємося на роботи І.Ардашкіна, В.Воронкової, М.Кастельса, О.Кивлюк, К.Корсака, А.Лазаревича, Р.Олексенка, О.Пунченка, в яких у тій чи іншій мірі відобразилася проблема становлення смарт-суспільства. Методологія дослідження - діалектичний, історичний, системний, інформаціологічний методи, які дозволили глибоко проникнути в еволюцію філософського знання, яке не стоїть на місці, а розвивається разом з розвитком науки, техніки, технологій. Результат дослідження - в основі смарт-суспільства розвиток інформаційно-комп'ютерних технологій, які ведуть до прориву технологій та інноваційному розвитку. Відмічається, що реорганізація системи соціально-гуманітарної освіти у вищих навчальних закладах Білорусі, що відбувається, покликана підняти на високий рівень філософсько-світоглядну підготовку вітчизняних спеціалістів.

Ключові слова: філософія, соціокультурна ситуація, філософські вчення, «дух свободи», реорганізація філософсько-світоглядного знання, Білорусь, смарт-суспільство, смарт-технології

ВИШНЕВСКИЙ, М. И. - доктор философских наук, профессор, Заслуженный работник образования Республики Беларусь, заведующий кафедрой фиософии 
Могилевского государственного университета имени А. Кулешова (Могилев, Республика Белорусь)

E-mail: philos-mogilev-msu@ mail.ru, ORCID 0000-0001-6603-0534

\section{ФИЛОСОФСКОЕ ОБРАЗОВАНИЕ В КОНТЕКСТЕ ИДЕИ СМАРТ-ОБЩЕСТВА}

В статье представлена концептуализация философского образования, в контексте котрого происходит эволюция развития общества от инфрмационного до смартобщества. Цель статьи - раскрыть концептуализацию философского образования в контексте идеи смарт-общества и показать, что философское образование не стоит на месте, а развивается вместе с развитием науки и техники, что требует развития и понятийно-категориального аппарата. Задачи исследования: показать развитие философского знания, в контексте которого вызревают новые инновационные идеи; выявить, что концепция смарт-общества основывается на ожидании или убеждении в способности современных смарт-технологий благотворно повлиять на социальные процессы и привести к новому качественному состоянию всей общественной жизни, которое и называют смарт-обществом; доказать, что многое в решении всех этих проблем зависит от состояния образования, в том числе философскомировоззренческого, не только развивающего наши познавательные способности, но и формирующего ответственное и взыскательное отношение к целеполаганию, выбору базовых жизненных ценностей. Анализ последних исследований и публикаций, в которых представлено решение данной проблемы. Мы опираемся на работы И.Ардашкина, В.Воронковой, М.Кастельса, О.Кивлюк, К.Корсака, А.Лазаревича, Р.Олексенка, О.Пунченко, в которых в той или иной мере отразилась проблема становления смарт-общества. Методология исследования - диалектический, исторический, системный, информациологический методы, которые позволили глубоко проникнуть в эволюцию философского знания, которое не стоит на мессе, а развивается вместе с развитием науки, техники, технологий. Результат исследований - в основе смарт-общества развитие информационно-компьютерных технологий, которые ведут к прорыву технологий и инновационному развитию Отмечается, что намечаемая реорганизация системы социально-гуманитарного образования в вузах Республики Беларусь призвана поднять на должный уровень философско-мировоззренческую подготовку отечественных специалистов.

Ключевые слова: философия, социокультурная ситуация, философские учения, «дух свободы», реорганизация философско-образовательного знания, Беларусь, смартобщество, смарт-технологии

Стаття рекомендована до публікащії д.філософ.н., проф. В.Г.Воронковою

(Запоріжжя, Украӥна)

Надійшла до редколегії: 09.10.2018

Прийнята до друку: 14.10.2018

(C) Vishnevsky, M. I., 2018 